\title{
TEMPERATURES WITHIN FLOWERS \& STEMS: POSSIBLE ROLES IN PLANT REPRODUCTION IN THE NORTH
}

\author{
Peter G. Kevan ${ }^{1}$ Evgeniy A. Tikhmenev ${ }^{2}$ Patricia Nunes-Silva ${ }^{1}$ \\ ${ }^{1}$ School of Environmental Sciences, University of Guelph, Guelph, Ontario N1G 2W1, Canada \\ ${ }^{2}$ Institute of the Biological Problems of the North, \\ Far-Eastern Branch of the Russian Academy of Sciences, Magadan, Russia \\ E-mail: etikhmenev@bk.ru
}

\begin{abstract}
Temperature regimes within flowers and stems show that insolation (solar) warming results in temperature excesses above the ambient air. The additional heat is important for development of reproductive organs (sporophylls) and presumably for the growth of stems. We review studies on temperature regimes within flowers and note that there are almost none within stems. Temperature excesses above ambient air in flowers and within hollow stems are variable but can range up to about $10^{\circ} \mathrm{C}$. In the Magadan area, our cursory survey suggests that stem hollowness is more common (18:4 species) than in other parts of the world (about 50\%). Our results from recording temperatures with the hollow stems of four species of herbaceous plants (oats (Avena sativa), dandelion (Taraxacum officinale), thistle (Cirsium setosum) and sneezewort (Ptarmica salicifolia) in a direct sunlight in Magadan present temperature excesses from about $1^{\circ} \mathrm{C}$ to $7^{\circ} \mathrm{C}$ depending on species, location, and other factors. Flowering, seed-set, floral and seed presentation all require growth and development of plants which are generally stimulated by heat. The general effects of weather and temperature are highly influenced by micrometeorology within plant organs by biophysical processes that suggest adaptations for insolational heat capture. Our studies, although preliminary, open the door to a poorly studied area of micrometeorology.
\end{abstract}

\section{Keywords: microgreenhouse, hollow stems, plant growth, micrometeorology, plant develop-} ment, climate change, floral ecology, heliotropism.

\section{INTRODUCTION}

The growth rates of plants depend on various environmental factors, not the least of which in importance is temperature (Went, 1953). The importance of temperatures in plant ecology has been studied by bioclimatologists, micrometeorologists (Geiger et al., 2009; Jones, 2013) and plant physiologists (Chapin, 1983; Michaletz, 2018). However, in the context of modern concerns over the effects of climate change on plant growth and productivity, especially in respect to crop and forest productivity, there is a need for integrating climatological changes and micrometeorological effects with plants' physiological adaptations and constraints.

There are a new and large amounts of information in the modern scientific literature concerning the observed effects of climate change on plant distributions and to a lesser extent growth rates (Post, 2013). There have been major advances in micrometeorology and the effects of ambient temperatures, and other factors, on the growth and productivity of plants, especially for agriculture and forestry (Jones, 2013). In respect to the reproductive eco-logy of northern and alpine plants, several recent papers have pointed out the consequences of recently documented phe-

(C) Kevan Peter G., Tikhmenev Evgeniy A., Nunes-Silva Patricia, 2019 nological mismatches in pollination through pollinator availability and activity and flowering times (Høye et al., 2013; Miller-Struttmann et al., 2015; Wheeler et al., 2015). What is emerging in studies about the issues noted above are the interrelationships between climate change, ambient meteorological and micrometeorological conditions, and the micrometeorology within individual plants and within their reproductive structures.

The recorded phenological mismatches are influencing the reproductive outputs of various species of plants and altering the relationships that pollinating insects have with those plants. Part of the acknowledged suite of problems has been attributed to the temperatures with in flowers (Shrestha et al., 2018). Intrafloral temperature regimes have been studied with respect to pollination biology especially in alpine and arctic locales (Krog, 1955; Büdel, 1956, 1957, 1959a, b; Hocking, Sharplin, 1965; Hocking, 1968; Kevan, 1970, 1972, 1975, 1989, 1990, 2007, 2013; Lack, 1976; Mølgaard, 1982, 1989; Stanton, Galen, 1989, 1993; Corbett et al., 1992; Krannitz, 1996; McKee, Richards, 1998; Galen, Stanton, 2003; Galen, 2006; Zhang et al., 2010; Harrap et al., 2017) and with concern for pollinator/flowering phenological mismatches (Høye et al., 2013; Miller-Struttmann et al., 2015; Wheeler et al., 2015). It is acknowledged that intrafloral thermal regimes influence the growth 
and presentation of the sexual organs (flowers and inflorescences) (Sørensen, 1941; Krog, 1955; Warren, Wilson, 1957; Tikhomirov et al., 1960; Shamurin, 1966; Corbet, 1972; Savile, 1972; Kevan ,1970, 1975, 1989; Tikhmenev, 1976, 1984, 1997; Mølgaard, 1982, 1989; Kevan et al., 1993). However, there are few studies on how supporting structures (stems, peduncles, culms etc.) capture and use ambient heat (including solar radiation) to enhance their presentations for pollination (by insects or by wind) or for seed/fruit dispersal (mostly by wind) (Kevan et al., 2018). The innovative study by Meier (1995) approached the question for two species of Pedicularis, $P$. lanata and $P$. hirsuta (Scrophulariaceae) and two species of stem boring insects (Olethreutes inquietana (Lepidoptera; Tortricidea) and Gonarcticus arcticus (Diptera; Scathophagidae) in the Canadian High Arctic. She found that the temperatures in the stems of both species of Pedicula-ris were greater than the ambient air and were influenced by time of day, aspect, and pubescence.

Kevan et al. (2018) introduced new approaches that can be applied to understanding heat accumulation in hollow stems. The International Conference on Biological Problems of the North provides an opportunity to share ideas, to review information on intrafloral temperatures and to present concepts about temperature regimes in hollow stems of herbaceous plants and to present some preliminary findings from the Magadan region of Far Northeastern Russia.

\section{METHODS}

To review briefly information on intrafloral temperatures and how they may become generated, the current literature was consulted and summarized (Table 1).

During the short study period, a casual survey of herbaceous plants still in flower was made to gather some preliminary information on the incidence of hollow stems (Table 2). Plant stems were simply cut with a sharp knife and recorded as hollow or as solid. Specimens were taken to IPBN for taxonomic identification by Dr. Maria Khoreva. Nomenclature follows Berkutenko et al. (2010).

The temperatures within the hollow stems of herbaceous plants were measured by copper-constantan thermocouples and a 4-channel Omega RDXL4SD SD Card Data Logger Thermometer(Figures 2 and 3). The measurements were taken by inserting one thermocouple into the plant stem while the ambient air temperature was measured by a second, identical, thermocouple suspended in the shade about $1 \mathrm{~cm}$ away from the stem under study. The paired measurements were recorded by hand about 2 seconds apart.

One crop species and three species of ruderal plants were studied over two days of sunny and calm weather. On 26 September, 2018, between 13:00 and 13:30, oats (Avena sativa (Poaceae) growing in farmer's field on the northern outskirts of Magadan (Figure 1) were removed from the field, and two culms were studied. The plants were over 2 metres tall with culm diameters of about $1 \mathrm{~cm}$ with still green fruiting heads (Figure 1). Also on 26 September, 2018, but between 10:30 and 11:00, the peduncles of two plants of dandelion (Taraxacum officinale (Asteraceae)) at Snow Valley, north of Magadan were studied (Figure 2). Temperatures within, and adjacent to, the peduncles of four flowering plants of thistle (Cirsium setosum (Asteraceae)) in two separate sites in the city of Magadan were studied between 13:00 and 13:30 on 25 September, 2018. The plants had statures of about 1.5 to 2 meters and stem diameters of about $1.5 \mathrm{~cm}$. On the day before and the next day, peduncles of four flowering plants of Ptarmica salicifolia (Asteraceae) (Figure 3) were studied at IPBN in Magadan on 25 September, 2018 and in Snow Valley on 26 September, 2018 between 13:30 and 14:00 and 10:00 and 10:30, respectively).

The temperatures recorded were subjected to statistical analyses according to the following Null hypothesis: Ho: Plant stems take on the temperature of the surrounding, ambient air. Paired Student's t-tests were applied to the results collected for each stem. The ambient air temperatures for each of the experiments on two plants and the temperatures within the two stems were compared by unpaired Student's t-test to assess whether or not the temperatures of the ambient air differed significantly and to assess whether or not the temperatures of the air within the stems differed significantly. The suite of results for all temperatures (ambient and within stems) in each experiment ( 2 plants at each site) were subject to 1-way ANOVA to assess whether or not it could be appropriate to combine results. When results from four plants ( 2 plants per site) were available, the results were also subjected to 1-way ANOVA to assess whether or not it could be appropriate to combine results. Statistical testing was made through PAST 3.21 (Hammer et al., 2001).

\section{RESULTS}

Table 2 suggest that the herbaceous flora in the region of Magadan comprises more species with hollow peduncles than other parts of the world (e. g. Canada and U. K.).

Observations on 2 plants of farm grown oats (Figure 1) indicate statistical differences between the ambient temperatures and temperatures within the hollow stems (Table 3 ) .

The temperatures within the oat stems (culms) of both plants were statistically different (warmer) than the ambient air temperature and all temperatures were statistically different from each other (Table 3 ). However, both plants showed similar differences in temperatures between the ambient air and within the stems (culms; Table 3). 
Table 1. Brief summary of the various ways that flowers may become warmer than the ambient air temperatures (Temperature excesses), with examples from northern regions

Таблица 1. Краткий обзор способов повышения температуры цветков по сравнению с температурой окружающего воздуха (превышения температур) с примерами из северных регионов

\begin{tabular}{|c|c|c|c|}
\hline $\begin{array}{c}\text { Mechanism } \\
\text { of Temperature Elevation }\end{array}$ & Examples & Notes & References \\
\hline $\begin{array}{l}\text { Sphercial solar radia- } \\
\text { tion accumulators }\end{array}$ & $\begin{array}{l}\text { Dryas spp., Ranunculus } \\
\text { spp., Anenome spp., Po- } \\
\text { tentilla } \text { spp. }\end{array}$ & $\begin{array}{l}\text { Some may be diahelio- } \\
\text { tropic for all or part of } \\
\text { sunny days with minimal } \\
\text { wind }\end{array}$ & $\begin{array}{l}\text { Büdel, 1959a, b; Hocking, Sharplin, } \\
\text { 1965; Hocking, 1968; Kevan, 1970, } \\
\text { 1972, 1989, 2007, 2013; Kjellberg et } \\
\text { al., 1982; Stanton, Galen, 1989; Kran- } \\
\text { nitz, 1996; Galen et al., 2003; Galen, } \\
\text { 2006; Zhang et al., 2010; Serrano et } \\
\text { al., 2018; Kooi, C. van der et al., } \\
2017\end{array}$ \\
\hline Discs & Various Asteraceae & $\begin{array}{l}\text { Some may be diahelio- } \\
\text { tropic for all or part of } \\
\text { sunny days with minimal } \\
\text { wind }\end{array}$ & $\begin{array}{l}\text { Büdel, 1959a, b; Shamurin, 1966; } \\
\text { Kevan, 1970, 1989; Atamian et al., } \\
2016\end{array}$ \\
\hline Open funnels & $\begin{array}{l}\text { Saxifragaceae, Brassica- } \\
\text { ceae, various Caryophyl- } \\
\text { laceae }\end{array}$ & $\begin{array}{l}\text { The great variations re- } \\
\text { corded between species } \\
\text { in the Arctic have not } \\
\text { been explained }\end{array}$ & Kevan, 2007; Mølgaard, 1982 \\
\hline $\begin{array}{l}\text { Microgreenhouse } \\
\text { effects in enclosed } \\
\text { flowers }\end{array}$ & $\begin{array}{l}\text { Pedicularis spp., Lychnis } \\
\text { (Melandrium, Silene) } \\
\text { spp., many plants have } \\
\text { zygomorphic flowers that } \\
\text { enclose air within }\end{array}$ & $\begin{array}{l}\text { This phenomenon has } \\
\text { been rarely explored }\end{array}$ & Kevan, 1970, 1989; Meier, 1995 \\
\hline $\begin{array}{l}\text { Pubescent radiation } \\
\text { accumulators and in- } \\
\text { sulation }\end{array}$ & Salix spp. & $\begin{array}{l}\text { Temperatures in stamin- } \\
\text { ate catkins are lower than } \\
\text { in pistillate ones }\end{array}$ & $\begin{array}{l}\text { Krog, 1955; Büdel, 1957; Kevan, } \\
\text { 1970, 1989, 1990; Mølgaard, } 1982\end{array}$ \\
\hline $\begin{array}{l}\text { Hanging cups trap- } \\
\text { ping convected heat }\end{array}$ & $\begin{array}{l}\text { Various Ericaceae, Mer- } \\
\text { tensia } \text { spp., Campanula } \\
\text { spp. }\end{array}$ & - & Büdel, 1959a; Kevan, 1970, 1989 \\
\hline $\begin{array}{l}\text { Epinastic closing } \\
\text { under shady condi- } \\
\text { tions }\end{array}$ & $\begin{array}{l}\text { Gentiana procera, some } \\
\text { Brassicaceae, Astercaeae }\end{array}$ & - & - \\
\hline Coloration & - & $\begin{array}{l}\text { Comparisons between } \\
\text { flowers of different col- } \\
\text { ours of the same species } \\
\text { remain to be made. White } \\
\text { flowers of the diahelio- } \\
\text { tropic arctic poppy are } \\
\text { cooler that yellow ones } \\
\text { under the same sunny } \\
\text { conditions }\end{array}$ & $\begin{array}{l}\text { Mølgaard, 1989; McKee, Richards, } \\
\text { 1998; Harrap et al., 2017; Shrestha } \\
\text { et al., 2018; Kooi, C. van der et al., } \\
2017\end{array}$ \\
\hline
\end{tabular}

For dandelions, the temperatures within the stems (peduncles) of both plants were statistically different (warmer) than the ambient air temperature and all temperatures were statistically different from each other (Table 4). Both plants showed statistically significant differences in temperatures between the ambient air and within the stems (peduncles; Table 4).

C. setosum presented similar results for both study sites. The temperatures within the stems (peduncles) of both plants were statistically different (warmer) than the ambient air temperature and all temperatures were statistically different from each other (Table 5). However, both plants showed similar differences in temperatures between the ambient air and within the stems (peduncles). Furthermore, all differences between stems (peduncles) and ambient air temperatures are only slightly significantly different from each other (Table 5). The temperature differences between stems 1,2 and 4 were not significantly different, nor were the differences between stems 2,3 and 4 . The only difference was between stems 1 and 3 (Tukey's $Q=4.21$; 
Table 2. Results of preliminary survey of herbaceous plants in Magadanskaya Oblast and the incidence of hollow and solid stems

Таблица 2. Результаты предварительного изучения травянистых растений в Магаданской области и совпадения по полым и мясистым стеблям

\begin{tabular}{|c|c|c|c|}
\hline Family & Genus \& Species & $\begin{array}{l}\text { Hollow }(\mathrm{H}) \text { or } \\
\text { Solid }(\mathrm{S}) \text { stem }\end{array}$ & Notes \\
\hline \multirow{9}{*}{ Asteraceae } & Cacalia hastata & $\mathrm{H}$ & As in Canada, UK \\
\hline & Taraxacum officinale & $\mathrm{H}$ & $-"-$ \\
\hline & Matricaria enodorum & $\mathrm{S}$ & -"- \\
\hline & Achillea millefolium & $\mathrm{S}$ & $-"-$ \\
\hline & Cirsium setosum & $\mathrm{H}$ & Other Cirsium spp. elsewhere have solid peduncles \\
\hline & Artemisia leucophila & $\mathrm{H}$ & - \\
\hline & Ptarmica salicifolia & $\mathrm{H}$ & - \\
\hline & Tanacetum vulgare & $\mathrm{H}$ & $\begin{array}{l}\text { This species has solid peduncles where sampled in } \\
\text { Canada }\end{array}$ \\
\hline & Solidago spiraefolia & $\mathrm{S}$ & $\begin{array}{l}\text { Other Solidago spp. Sampled elsewhere also have } \\
\text { solid peduncles }\end{array}$ \\
\hline Onagraceae & $\begin{array}{l}\text { Chamaerion angusi- } \\
\text { folium }\end{array}$ & $\mathrm{S}$ & As in Canada, UK \\
\hline Ranunculaceae & Delphinium sp. & $\mathrm{H}$ & - \\
\hline \multirow{2}{*}{ Apiacea } & Angelica gmelinii & $\mathrm{H}$ & \multirow{2}{*}{ Many Apiacea have hollow peduncles } \\
\hline & Ligusticum scoticum & $\mathrm{H}$ & \\
\hline \multirow{3}{*}{ Poaceae } & Avena sativa & $\mathrm{H}$ & \multirow{3}{*}{ Paoaceae so far examined have hollow culms } \\
\hline & $\begin{array}{l}\text { Calamogrostis langs- } \\
\text { dorfii }\end{array}$ & $\mathrm{H}$ & \\
\hline & Elymus sp. & $\mathrm{H}$ & \\
\hline Scrophulariaceae & Rhinanthus aestivalis & $\mathrm{H}$ or $\mathrm{S}$ & Both forms were found in Magadan area \\
\hline \multirow{2}{*}{ Rosaceae } & Potentilla fragmaformis & $\mathrm{H}$ & - \\
\hline & Filipendula palmata & $\mathrm{H}$ & - \\
\hline Boraginaceae & Mertensia maritima & $\mathrm{H}$ & Lumen narrow \\
\hline Polygonaceae & Rumex aquatile & $\mathrm{H}$ & - \\
\hline Plantaginaceae & Plantago major & $\mathrm{H}$ & $\begin{array}{l}\text { Hollow is slit-like. This species sampled in Canada } \\
\text { has solid peduncle }\end{array}$ \\
\hline Cornaceae & Cornus suecicum & $\mathrm{H}$ & - \\
\hline
\end{tabular}

Note. Number of Hollow stemmed species $=18$. Number of Solid stemmed species $=4 ; \chi^{2}=6.23 ; \mathrm{p}=0.013$ [Based on 15:4 $(3$ grasses (Poacaea) excluded) vs. 'expected' at 49\% with hollow (94 of 192) stems (unpublished and preliminary data gathered in 2017 and 2018 mostly in Canada, but some from UK)].

$\mathrm{p}=0.028)$. For $S$. salicifolia the temperatures within the stems (peduncles) of both plants were statistically different (warmer) than the ambient air temperature and all temperatures were statistically different from each other (Table 6). However, plants 3 and 4 on site 2 (Snow Valley), unlike 1 and 2 on site 1 (Madagan), showed similar differences in temperatures between the ambient air and within the stems (peduncles) (Table 6). Regarding all differences between stems (peduncles) and ambient air temperatures, they are highly significantly different from each other (Table 6). However, the temperature differences between stems 2 and 4 and between 3 and 4 are not significantly different (Table 6).

Fig. 1. Oats (Avena sativa) on the farm of G. Bezuglov (on left) north of Magadan. PGK is on the right

Puc. 1. Овес Avena sativa на ферме Г. Безуглова (слева) к северу от Магадана. Справа - профессор П. Г. Кеван

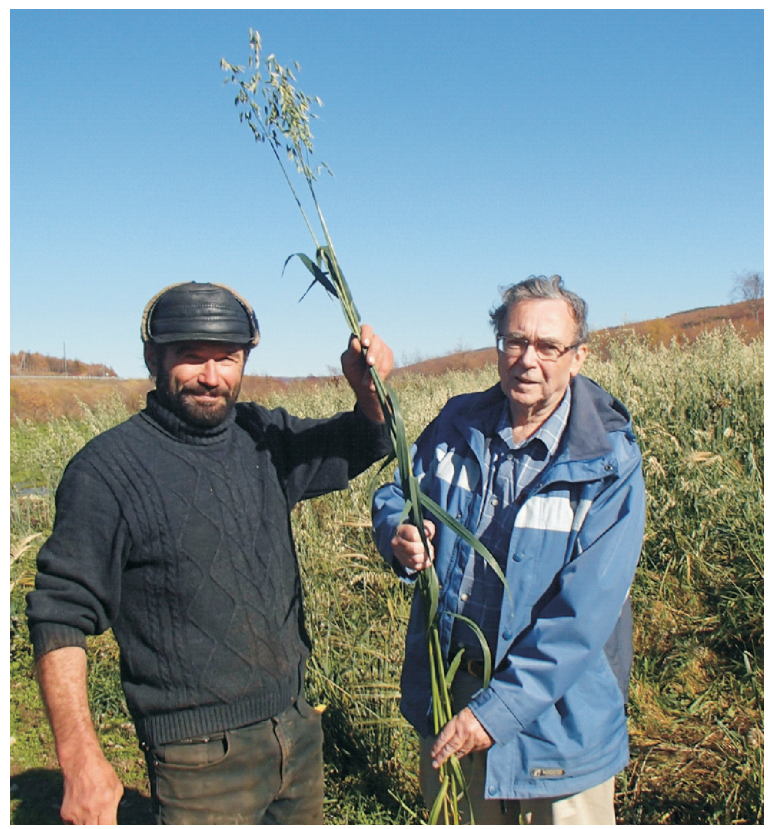


Table 3. Ambient air temperatures and temperatures within the culms of two plants of oats Avena sativa (Poaceae) at the farm of G. Bezuglov in Magadan, Russia between 13:00 and 13:30 on 26 September, 2018 together with the temperature differences $\left(\mathrm{T}^{\circ} \mathrm{C}\right.$ diff.) between the ambient air and within the culms. Statistical values for mean temperatures, their standard deviations and comparisons by Paired and un-paired t-tests and by ANOVA are included

Таблица 3. Температуры окружающего воздуха и внутри соломин двух растений овса Avena sativa (Роасеае) на ферме Г. Безуглова в Магадане (Россия) между 13:00 и 13:30 26 сентября 2018 г., а также разницы температур (T, ${ }^{\circ} \mathrm{C}$ diff.) окружающего воздуха и внутри соломин. Включены статистические значения средних температур, их стандартные отклонения и сравнения посредством парных и непарных t-критериев и ANOVA

\begin{tabular}{|c|c|c|c|c|c|c|c|c|}
\hline $\begin{array}{c}\text { Plant } \\
\#\end{array}$ & $\mathrm{~T}^{\circ} \mathrm{C}$ air & $\mathrm{T}^{\mathrm{o}} \mathrm{C}$ culm & $\begin{array}{c}\mathrm{T}^{\circ} \mathrm{C} \text { air vs. } \mathrm{T}^{\circ} \mathrm{C} \\
\text { culm (Paired } \\
\mathrm{t} \text { test) }\end{array}$ & $\begin{array}{l}\text { Comparison all } \\
\mathrm{T}^{\circ} \mathrm{C} \text { (ANOVA) }\end{array}$ & $\begin{array}{c}\mathrm{T}^{\mathrm{b}} \mathrm{C} \text { culm } \\
\text { plant } 1 \text { vs. } 2 \\
(\mathrm{t} \text { test })\end{array}$ & $\begin{array}{l}\mathrm{T}^{\circ} \mathrm{C} \text { air } \\
\text { plant } 1 \text { vs. } \\
2 \text { (t test) }\end{array}$ & $\mathrm{T}^{\circ} \mathrm{C}$ diff. & $\begin{array}{c}\mathrm{T}^{\mathrm{O}} \mathrm{C} \text { diff. } \\
\text { plant } 1 \text { vs. } 2 \\
(\mathrm{t} \text { test) }\end{array}$ \\
\hline 1 & $16.15 \pm 0.64$ & $20.45 \pm 0.68$ & $\begin{array}{l}\mathrm{t}=10.89 \\
\mathrm{p}<0.001\end{array}$ & \multirow{2}{*}{$\begin{array}{c}\mathrm{F}_{3.40}=208.5 \\
\mathrm{p}<0.0001\end{array}$} & \multirow{2}{*}{$\begin{array}{c}\mathrm{t}=4.11 \\
\mathrm{p}<0.001\end{array}$} & \multirow{2}{*}{$\begin{array}{c}\mathrm{t}=3.56 \\
\mathrm{p}<0.002\end{array}$} & $4.24 \pm 1.40$ & \multirow{2}{*}{$\begin{array}{l}\mathrm{t}=0.44 \\
\mathrm{p}=0.33\end{array}$} \\
\hline 2 & $15.13 \pm 0.68$ & $19.57 \pm 0.17$ & $\begin{array}{l}\mathrm{t}=19.76 \\
\mathrm{p}<0.001\end{array}$ & & & & $4.45 \pm 0.74$ & \\
\hline
\end{tabular}
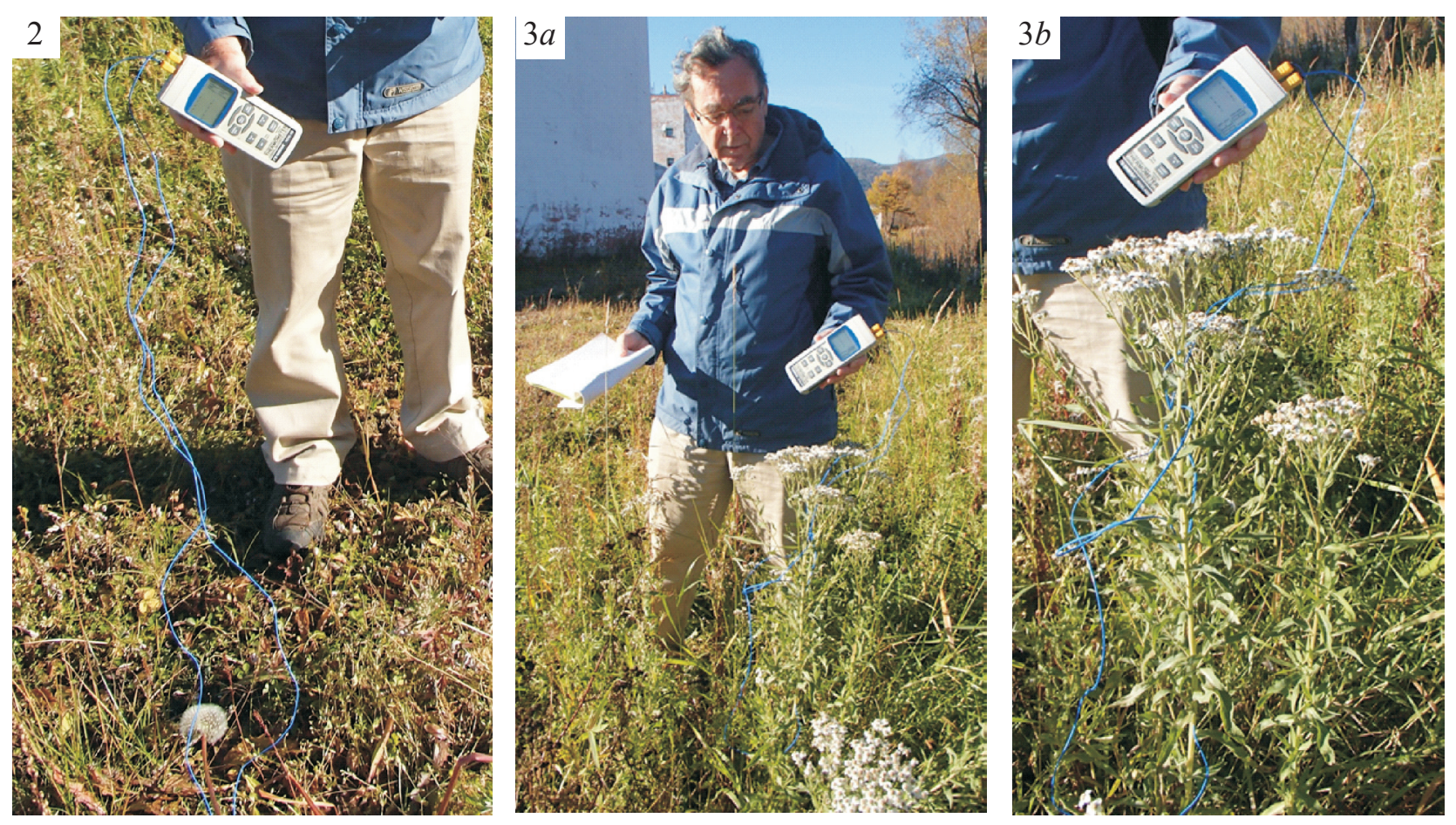

Fig. 2 and 3. Measuring the temperatures in the peduncles of Taraxacum officinale (Figure 2, left) and Ptarmica salicifolia (Figure $3 a$ and $b$, middle and right). Blue wires are from the thermocouples inserted in the peduncle or in the ambient air and connected to the Omega RDXL4SD data logger

Puc. 2, 3. Замер температур в цветоножках Taraxacum officinale (рис. 2, слева) и Ptarmica salicifolia (рис. 3, a и 6 , в середине и справа). Синие провода идут от термопар, введенных в цветоножку или находящихся в окружающем воздухе и подсоединенных к Omega. Регистратор данных RDXL4SD

Tukey's Q comparisons between the stems range from $5.77(\mathrm{p}=0.001)$ to $13.41(\mathrm{p}<0.0001)$.

\section{DISCUSSION}

Although there are studies on the surface temperatures of various plant parts (Geiger et al., 2009; Jones, 2013) there are few studies of the temperatures within the stems of plants. An unique study seems to be that of Meier (1995) who recorded the temperatures in the flowers and stems of two Arctic species of Pedicularis as greater than the ambient air and influenced by time of day, aspect, pubescence and stem boring insects. Kevan et al. (2018) present a biophysical model for microgreenhouse effects for solar radiant heat accumulation in hollow stems of herbaceaous plants, such as we studied in Magadan. Our findings from the Magadan region (Tables 2 to 6) accord in principal and magnitude with those presented in Kevan et al. (2018).

At present, there are insufficient data from anywhere in the world to make even tentative conclusions about the biogeographic distributions of her- 
Table 4. Ambient air temperatures and temperatures within the peduncles of two plants of dandelion Taraxacum officinale (Asteraceae) at Snow Valley, north of Magadan, Russia between 10:30 and 11:00 on 26 September, 2018 together with the temperature differences $\left(\mathrm{T}^{\circ} \mathrm{C}\right.$ diff.) between the ambient air and within the peduncles. Statistical values for mean temperatures, their standard deviations and comparisons by Paired and un-paired t-tests and by ANOVA are included

Таблица 4. Температуры окружающего воздуха и внутри цветоножек двух растений одуванчика Taraxacum officinale (Asteraceae) в Снежной Долине к северу от Магадана (Россия) между 10:30 и 11:00 26 сентября 2018 г., а также разницы температур (T, ${ }^{\circ} \mathrm{C}$ diff.) окружающего воздуха и внутри цветоножек. Включены статистические значения средних температур, их стандартные отклонения и сравнения посредством парных и непарных t-критериев и ANOVA

\begin{tabular}{|c|c|c|c|c|c|c|c|c|}
\hline $\begin{array}{c}\text { Plant } \\
\#\end{array}$ & $\mathrm{~T}^{\circ} \mathrm{C}$ air & $\mathrm{T}^{\circ} \mathrm{C}$ peduncle & $\begin{array}{l}\mathrm{T}^{\circ} \mathrm{C} \text { air vs. } \\
\mathrm{T}^{\circ} \mathrm{C} \text { peduncle } \\
\text { (Paired t test) }\end{array}$ & $\begin{array}{l}\text { Comparison all } \\
\mathrm{T}^{\circ} \mathrm{C} \text { (ANOVA) }\end{array}$ & $\begin{array}{c}\mathrm{T}^{\mathrm{o}} \mathrm{C} \\
\text { peduncle } \\
\text { plant } 1 \mathrm{vs} .2 \\
\text { (t test) }\end{array}$ & $\begin{array}{c}\mathrm{T}^{\circ} \mathrm{C} \text { air plant } \\
1 \text { vs. } 2 \\
(\mathrm{t} \text { test })\end{array}$ & $\mathrm{T}^{\circ} \mathrm{C}$ diff. & $\begin{array}{l}\mathrm{T}^{\circ} \mathrm{C} \text { diff. } \\
\text { plant } 1 \text { vs. } \\
2 \text { ( } \mathrm{t} \text { test) }\end{array}$ \\
\hline 1 & $12.68 \pm 0.61$ & $18.79 \pm 1.47$ & $\begin{array}{c}\mathrm{t}=10.65 \\
\mathrm{p}<0.0001\end{array}$ & \multirow{2}{*}{$\begin{array}{c}\mathrm{F}_{3.40}=140.9 \\
\mathrm{p}<0.0001\end{array}$} & \multirow{2}{*}{$\begin{array}{c}\mathrm{t}=5.85 \\
\mathrm{p}<0.0001\end{array}$} & \multirow{2}{*}{$\begin{array}{c}\mathrm{t}=3.58 \\
\mathrm{p}<0.001\end{array}$} & $6.07 \pm 1.81$ & \multirow{2}{*}{$\begin{array}{c}\mathrm{t}=3.40 \\
\mathrm{p}=0.001\end{array}$} \\
\hline 2 & $11.96 \pm 0.31$ & $15.96 \pm 0.74$ & $\begin{array}{c}\mathrm{t}=15.07 \\
\mathrm{p}<0.0001\end{array}$ & & & & $4.04 \pm 0.92$ & \\
\hline
\end{tabular}

baceaous plants with hollow versus solid stems. Some of the findings from the Magadan area differ from findings elsewhere (Table 2) and even within the same area (e. g. Rhinanthus aestivalis).

The temperature excesses in both oat culms (Table 3) were about $4^{\circ} \mathrm{C}$. In dandelion, the temperature excesses were about $4^{\circ} \mathrm{C}$ and $6^{\circ} \mathrm{C}$ (Table 4), which are similar to those measured in Canada (Kevan et al., 2018). In C. setosum, temperature excesses were about $2^{\circ} \mathrm{C}$, similar in both locations in Magadan (Table 5). Temperature excesses in peduncles of $P$. salicifolia were the most variable between plants and sites ranging from about $1^{\circ} \mathrm{C}$ to over $4^{\circ} \mathrm{C}$ (Table 6). At present studies on the temperature excesses within hollow stems of herbaceaous plants are in their infancy so it is not possible to conjecture why the differences exist among plant species and individuals within the same species occur. Certainly there is great variability between sites, aspect, and plants' characteristics that presumably greatly influence insolational heating effects that only more detailed studies can elucidate.

From the brief summary of how flowers become warmed by capturing radiant solar heat (Table 1), it is evident that the most studied phenomenon is that of the dish or bowl shaped parabolic/spheric reflectors, especially for those species that show diaheliotropism (rotating to follow the trajectory of the sun). It has been demonstrated that the parts of the flower (corolla and sporophylls) contribute to the accumulation of heat. Kevan (1970) showed that flowers without sporophylls (excised) became as hot as complete flowers when directly facing the sun, but the heat accumulation diminished more or less linearly as the angle of solar incidence decreased. Numerous species of plants produce open bowl shaped flowers that are not diaheliotropic, but the findings reported by Kevan (1970) indicate that elevated temperatures would be expected as long as flowers were oriented within about 60 degrees of normal to incoming insolation. That could amount to approximately 8 or more hours (depending on latitude and angles of solar incidence) of effective additional insolational temperature elevation each day even without diaheliotropism. The combinational effects of the angle of solar insolation, floral shape, and floral orientation remain to be fully studied.

Diaheliotropism is well known in Asteraceae, with sunflower (Helianthus annuus) as the best studied species (Atamian et al., 2016). Temperature excesses have been attributed to insolation (Atamian et al., 2016) and Kevan (1970) recorded that the temperature excess in the Arctic dandelion, Taraxacum arctogenum, varied simply as the cosine of the incidence of insolation. Thus the temperature excess in the inflorescence is halved by the time the incidence of insolation has deviated 45 degrees from direct.

Many flowers are shaped like open funnels, or bells, oriented more or less to the sky. The mechanisms of temperature accumulations with respect to angle of insolation are not understood, but orientation and coloration are two characteristics that contribute. The form of the curve relating intrafloral temperature with the angle of solar incidence (Kevan, 1970, 2007) possibly suggests that the central part of the corolla functions as a radiant heat trapping parabolic/spheric bowl (see above).

Flowers that enclose air within them have rarely been studied. Kevan $(1970,1989)$ and McKee and Richards (1988) hypothesized that they function as microgreenhouses; insolation enters the enclosed cavity, is absorbed by the sprophylls within, and reradiated heat becomes trapped to warm the interior of the flower and its enclosed atmosphere (Kevan et al., 2018). Temperature excesses in such flowers are strongly influenced by the angle of insolation and the floral form. Flowers presenting globular, 
Table 5. Ambient air temperatures and temperatures within the peduncles of four plants of Cirsium setosum (Asteraceae) in two separate sites in Magadan, Russia between 10:30 and 11:00 on 25 September, 2018 together with the temperature differences $\left(\mathrm{T}^{ } \mathrm{C}\right.$ diff.) between the ambient air and within the peduncles. Statistical values for mean temperatures, their standard deviations and comparisons by Paired and un-paired t-tests and by ANOVA are included

Таблица 5. Температуры окружающего воздуха и внутри цветоножек четырех растений Cirsium setosum (Asteraceae) на двух разных участках в Магадане (Россия) между 10:30 и 11:00 25 сентября 2018 г., a также разницы температур ( $T$, ${ }^{\circ} \mathrm{C}$ diff.) окружающего воздуха и внутри цветоножек. Включены статистические значения средних температур, их стандартные отклонения и сравнения посредством парных и непарных t-критериев и ANOVA

\begin{tabular}{|c|c|c|c|c|c|c|c|c|}
\hline \multicolumn{9}{|c|}{ Site 1} \\
\hline $\begin{array}{c}\text { Plant } \\
\#\end{array}$ & $\mathrm{~T}^{\circ} \mathrm{C}$ air & $\mathrm{T}^{\circ} \mathrm{C}$ peduncle & $\begin{array}{c}\mathrm{T}^{ } \mathrm{C} \text { air vs. } \\
\mathrm{T}^{\mathrm{o}} \mathrm{C} \text { peduncle } \\
\text { (Paired t test) }\end{array}$ & $\begin{array}{l}\text { Comparison } \\
\text { all T' } \mathrm{C} \\
\text { (ANOVA) }\end{array}$ & $\begin{array}{l}\mathrm{T}^{\mathrm{o}} \mathrm{C} \text { peduncle } \\
\text { plant } 1 \text { vs. } 2 \\
\text { ( } \mathrm{t} \text { test })\end{array}$ & $\begin{array}{c}\mathrm{T}^{\circ} \mathrm{C} \text { air plant } \\
1 \text { vs. } 2(\mathrm{t} \\
\text { test })\end{array}$ & $\mathrm{T}^{\circ} \mathrm{C}$ diff. & $\begin{array}{l}\mathrm{T}^{\mathrm{o}} \mathrm{C} \text { diff. } \\
\text { plant } 1 \text { vs. } \\
2 \text { ( } \mathrm{t} \text { test })\end{array}$ \\
\hline 1 & $16.41 \pm 0.61$ & $19.07 \pm 1.0$ & $\begin{array}{l}\mathrm{t}=11.95 \\
\mathrm{p}<0.001\end{array}$ & \multirow{2}{*}{$\begin{array}{c}\mathrm{F}_{3.30}=83.62 \\
\mathrm{p}<0.0001\end{array}$} & \multirow{2}{*}{$\begin{array}{c}\mathrm{t}=19.18 \\
\mathrm{p}<0.0001\end{array}$} & \multirow{2}{*}{$\begin{array}{c}\mathrm{t}=4.71 \\
\mathrm{p}<0.0003\end{array}$} & $2.66 \pm 0.63$ & \multirow{2}{*}{$\begin{array}{l}t=0.73 \\
p=0.48\end{array}$} \\
\hline 2 & $14.58 \pm 0.94$ & $16.97 \pm 0.29$ & $\begin{aligned} \mathrm{t} & =8.20 \\
\mathrm{p} & <0.001\end{aligned}$ & & & & $2.39 \pm 0.87$ & \\
\hline \multicolumn{9}{|c|}{ Site 2} \\
\hline $\begin{array}{c}\text { Plant } \\
\#\end{array}$ & $\mathrm{~T}^{\circ} \mathrm{C}$ air & $\mathrm{T}^{\circ} \mathrm{C}$ peduncle & $\begin{array}{c}\mathrm{T}^{\circ} \mathrm{C} \text { air vs. } \\
\mathrm{T}^{\circ} \mathrm{C} \text { peduncle } \\
\text { (Paired } \mathrm{t} \text { test) }\end{array}$ & $\begin{array}{c}\text { Comparison } \\
\text { all } \mathrm{T}^{\circ} \mathrm{C} \\
\text { (ANOVA) }\end{array}$ & $\begin{array}{c}\mathrm{T}^{\circ} \mathrm{C} \text { peduncle } \\
\text { plant } 1 \text { vs. } 2 \\
(\mathrm{t} \text { test })\end{array}$ & $\begin{array}{c}\mathrm{T}^{\circ} \mathrm{C} \text { air plant } \\
1 \text { vs. } 2 \\
(\mathrm{t} \text { test })\end{array}$ & $\mathrm{T}^{\circ} \mathrm{C}$ diff. & $\begin{array}{c}\mathrm{T}^{\mathrm{C}} \mathrm{C} \text { diff. } \\
\text { plant } 1 \text { vs. } 2 \\
(\mathrm{t} \text { test })\end{array}$ \\
\hline 1 & $13.72 \pm 0.34$ & $15.44 \pm 0.21$ & $\begin{array}{l}\mathrm{t}=15.44 \\
\mathrm{p}<0.001\end{array}$ & \multirow{2}{*}{$\begin{array}{c}\mathrm{F}_{3.30}=122.3 \\
\mathrm{p}<0.0001\end{array}$} & \multirow{2}{*}{$\begin{array}{c}\mathrm{t}=7.81 \\
\mathrm{p}<0.0001\end{array}$} & \multirow{2}{*}{$\begin{array}{c}t=4.72 \\
p<0.0003\end{array}$} & $1.71 \pm 0.31$ & \multirow{2}{*}{$\begin{array}{l}\mathrm{t}=1.49 \\
\mathrm{p}=0.16\end{array}$} \\
\hline 2 & $14.52 \pm 0.36$ & $16.58 \pm 0.36$ & $\begin{array}{l}\mathrm{t}=10.69 \\
\mathrm{p}<0.001\end{array}$ & & & & $2.06 \pm 0.58$ & \\
\hline
\end{tabular}

Table 6. Ambient air temperatures and temperatures within the peduncles of four plants of Ptarmica salicifolia (Asteraceae) in Magadan on 25 September, 2018 and north of Magadan in Snow Valley on 26 September, 2018, Russia between 13:30 and 14:00 and 10:00 and 10:30, respectively, on 25 September, 2018 together with the temperature differences $\left(\mathrm{T}^{\circ} \mathrm{C}\right.$ diff.) between the ambient air and within the peduncles. Statistical values for mean temperatures, their standard deviations and comparisons by Paired and unpaired t-tests and by ANOVA are included

Таблица 6. Температуры окружающего воздуха и внутри цветоножек четырех растений Ptarmica salicifolia (Asteraceae) в Магадане (Россия) 25 сентября 2018 г. и к северу от Магадана, в Снежной Долине, 26 сентября 2018 г., между 13:30 и 14:00 и 10:00 и 10:30, соответственно, а также разницы температур (T, ${ }^{\circ} \mathrm{C}$ diff.) окружающего воздуха и внутри цветоножек. Включены статистические значения средних температур, их стандартные отклонения и сравнения посредством парных и непарных t-критериев и ANOVA

\begin{tabular}{|c|c|c|c|c|c|c|c|c|}
\hline \multicolumn{9}{|c|}{ Site 1: Madagan, IPBN } \\
\hline $\begin{array}{c}\text { Plant } \\
\text { \# }\end{array}$ & $\mathrm{T}^{\circ} \mathrm{C}$ air & $\mathrm{T}^{\circ} \mathrm{C}$ peduncle & $\begin{array}{l}\mathrm{T}^{\circ} \mathrm{C} \text { air vs. } \\
\mathrm{T}^{\circ} \mathrm{C} \text { peduncle } \\
\text { (Paired t test) }\end{array}$ & $\begin{array}{l}\text { Comparison all } \\
\mathrm{T}^{\circ} \mathrm{C} \text { (ANOVA) }\end{array}$ & $\begin{array}{c}\mathrm{T}^{\mathrm{o}} \mathrm{C} \text { peduncle } \\
\text { plant } 1 \text { vs. } 2 \\
(\mathrm{t} \text { test })\end{array}$ & $\begin{array}{c}\mathrm{T}^{\mathrm{O}} \mathrm{C} \text { air } \\
\text { plant } 1 \mathrm{vs} . \\
2 \text { ( t test) }\end{array}$ & $\mathrm{T}^{\circ} \mathrm{C}$ diff. & $\begin{array}{c}\mathrm{T}^{\circ} \mathrm{C} \text { diff. } \\
\text { plant } 1 \text { vs. } \\
2(\mathrm{t} \text { test })\end{array}$ \\
\hline 1 & $14.54 \pm 1.15$ & $13.31 \pm 0.70$ & $\begin{array}{c}\mathrm{t}=7.83 \\
\mathrm{p}<0.001\end{array}$ & \multirow{2}{*}{$\begin{array}{c}\mathrm{F}_{3.36}=125.7 \\
\mathrm{p}<0.0001\end{array}$} & \multirow{2}{*}{$\begin{array}{c}\mathrm{t}=12.19 \\
\mathrm{p}<0.0001\end{array}$} & \multirow{2}{*}{$\begin{array}{c}t=4.76 \\
p=0.0001\end{array}$} & $1.23 \pm 0.53$ & \multirow{2}{*}{$\begin{array}{c}\mathrm{t}=13.63 \\
\mathrm{p}<0.0001\end{array}$} \\
\hline 2 & $14.56 \pm 0.45$ & $19.21 \pm 0.37$ & $\begin{array}{l}\mathrm{t}=24.79 \\
\mathrm{p}<0.001\end{array}$ & & & & $4.65 \pm 0.59$ & \\
\hline \multicolumn{9}{|c|}{ Site 2: Snow Valley } \\
\hline $\begin{array}{c}\text { Plant } \\
\#\end{array}$ & $\mathrm{~T}^{\circ} \mathrm{C}$ air & $\mathrm{T}^{\circ} \mathrm{C}$ peduncle & $\begin{array}{l}\mathrm{T}^{\circ} \mathrm{C} \text { air vs. } \\
\mathrm{T}^{\circ} \mathrm{C} \text { peduncle } \\
\text { (Paired t test) }\end{array}$ & $\begin{array}{c}\text { Comparison } \\
\text { all } \mathrm{T}^{\circ} \mathrm{C} \\
\text { (ANOVA) } \\
\end{array}$ & $\begin{array}{c}\mathrm{T}^{\mathrm{o}} \mathrm{C} \text { peduncle } \\
\text { plant } 1 \text { vs. } 2 \\
(\mathrm{t} \text { test })\end{array}$ & $\begin{array}{l}\mathrm{T}^{\mathrm{o}} \mathrm{C} \text { air plant } \\
1 \text { vs. } 2(\mathrm{t} \text { test })\end{array}$ & $\mathrm{T}^{\circ} \mathrm{C}$ diff & \begin{tabular}{|c|}
$\mathrm{T}^{\mathrm{C}} \mathrm{C}$ diff. \\
plant 1 vs. 2 \\
$(\mathrm{t}$ test $)$ \\
\end{tabular} \\
\hline 1 & $14.06 \pm 0.98$ & $17.18 \pm 0.42$ & $\begin{array}{l}\mathrm{t}=11.99 \\
\mathrm{p}<0.001\end{array}$ & \multirow{2}{*}{$\begin{array}{c}\mathrm{F}_{3.34}=106.9 \\
\mathrm{p}<0.0001\end{array}$} & \multirow{2}{*}{$\begin{array}{c}\mathrm{t}=8.10 \\
\mathrm{p}<0.0001\end{array}$} & \multirow{2}{*}{$\begin{array}{c}t=6.20 \\
p<0.0001\end{array}$} & $3.12 \pm 0.78$ & \multirow{2}{*}{$\begin{array}{l}\mathrm{t}=1.43 \\
\mathrm{p}=0.17\end{array}$} \\
\hline 2 & $16.11 \pm 0.36$ & $19.90 \pm 0.93$ & $\begin{array}{l}\mathrm{t}=10.09 \\
\mathrm{p}<0.001\end{array}$ & & & & $3.79 \pm 1.19$ & \\
\hline
\end{tabular}

lantern-like forms (e. g. Melandrium spp.) are less influenced by floral orientation than bilaterally symmetrical flowers (e. g. Pedicularis) that are warmest when the greatest external surface area is insolated and coolest when insolation comes from the back of the flowers. 
Perhaps with similar microgreenhouse mechanisms, coupled with insulating pubescence to trap passively accumulated insolation, are "hairy heat traps". Various authors have noted that pubescence in Arctic and alpine plants contributes to their heat budgets (Johnson, 1975; Bickford, 2016), and it is known that pistillate catkins of willows (Salix spp.) attain higher temperatures than their staminate counterparts in sunshine (Krog, 1955; Büdel, 1957; Kevan, 1970; Mølgaard, 1982).

There are various species of plants that present their flowers as bells or urns directed more or less downwards. Such flowers have not been much studied with respect to intrafloral temperatures. They may capture rising convected heat from the ground in combination with microgreenhouse effects. Colouration may also be an important factor in absorbing radiant energy.

Two recent papers (Harrap et al., 2017; Shrestha et al., 2018) emphasize the effects of coloration, intrafloral temperatures, and pollinator visitation. Neither seems to recognize that floral form and orientation may be as, or more, important than colour. It seems that fertile ground for new research is a comprehensive approach to understanding the importance of the suite of floral characteristics in pollinator foraging, behaviour, and pollination.

\section{CONCLUSIONS}

Studies on the temperature regimes within flowers and stems show that insolation is an important factor in providing warmth, and for flowers that the warmth is important for development of reproductive organs (sporophylls). We note that there are few studies on temperature regimes within flowers (Table 1), and almost none within stems. Temperature excesses above ambient air in flowers and within stems are variable but can range up to about $10^{\circ} \mathrm{C}$. We invoke a number of biophysical processes that suggest adaptations for insolational heat capture. Those adaptations range from shape and colour of flowers and hollowness in plants' stems (Kevan et al., 2018). Our results from Magadan emphasise the novelty of the role of micrometeorology within the organs of plants and its likely importance in plant reproduction. Flowering, setting seed, floral and seed presentation all require growth and development of plants which are generally stimulated by heat. For understandings of the effects of weather and climate change, micrometeorology within plant organs is surely important.

\section{ACKNOWLEDGEMENTS}

We are grateful for the encouragement and financial assistance from IBPN that allowed PGK to attend the International Scientific Conference on biological problems of the North in Magadan, Russia from on 18-22 September, 2018, and to make the field observations over several day following. PGK thanks the Canadian Natural Sciences and Engineering Council for funds for the purchase of the instrumentation used. We thank the staff at IPBN for the translation of this submission into Russian. Charlotte Coats assisted with the preparation of the manuscript.

\section{REFERENCES}

Atamian, H. S.; Creux, N. M.; Brown, E. A.; Garner, A. G.; Blackman, B. K.; Harmer, S. L., 2016, Circadian Regulation of Sunflower Heliotropism, Floral Orientation, and Pollinator Visits, Science, 353, 587-590.

Berkutenko, A. N.; Lysenko D. S.; Khoreva M. G.; Mochalova O. A.; Polezhaev A. N.; Andrijanova E. A.; Sinelnikova N. V.; Yakubov V. V., 2010, Flora and Vegetation of Magadan Region (Checklist of Vascular Plants and Outline of Vegetation), Magadan, IBPN FEB RAS [In Russian].

Bickford, C. P., 2016, Ecophysiology of Leaf Trichomes, Functional Plant Biology, 43, 809-814.

Büdel, A., 1956, Das Mikroklima in Einer Blüte, Zeitschrift für Bienenforschung, 3, 185-190.

Büdel, A., 1957, Das Mikroklima der Männlichern Weidenblüte, Ibid., 4, 21-22.

Büdel, A., 1959a, In den Blüten Herrscht Ein Sonderklima, Südwestdeutsch Imker, 11, 102-108.

Büdel, A., 1959b, Das Mikroklima der Blüten in Bodennähe, Zeitschrift für Bienenforschung, 6, 131-140.

Chapin, F. S., 1983, Direct and Indirect Effects of Temperature on Arctic Plants, Polar Biology, 2, 47-52.

Corbet, P. S., 1972, The Microclimate of Arctic Plants and Animals, on Land and in Fresh Water, Acta Arctica, $18,1-43$.

Corbett, A. L.; Krannitz P. G.; Aarssen L. W., 1992, The Influence of Petals on Reproductive Success in the Arctic Poppy (Papaver radicatum), Canadian Journal of Botany, 70, 200-204.

Galen, C., 2006, Solar Furnaces or Swamp Coolers: Costs and Benefits of Water use by Solar-Tracking Flowers of the Alpine Snow Buttercup, Ranunculus adoneus Oecologia, 148, 195-201.

Galen, C.; Stanton, M. L., 2003, Sunny-Side Up : Flower Heliotropism as a Source of Parental Environmental Effects on Pollen Quality and Performance in the Snow Buttercup, Ranunculus adoneus (Ranunculaceae), American Journal of Botany, 90, 724-729.

Geiger, R.; Aron, R.; Todhunter, P., 2009, The Climate Near the Ground, $7^{\text {th }}$ Ed., Rowman \& Littlefield Publishing Group, Lanham, MD, USA.

Hammer, Ø.; Harper, D. A. T.; Ryan, P. D., 2001, PAST: Paleontological Statistics Software Package for Education and Data Analysis, Palaeontologia Electronica, 4, 1, http://palaeo-electronica.org/2001_1/past/ issue1_01.htm

Harrap, M. J. M.; Rands, S. A.; Hempel de Ibarra, N.; Whitney, H. M., 2017, The Diversity of Floral Temperature Patterns, and Their Use by Pollinators, eLife 2017;6:e31262, DOI: 10.7554/eLife.31262.

Hocking, B., 1968, Insect-Flower Associations in the High Arctic with Special Reference to Nectar, Oikos, 19, 359-388. 
Hocking, B.; Sharplin, C. D., 1965, Flower Basking by Arctic Insects, Nature, 206, 215.

Høye, T. T.; Post, E.; Schmidt, N. M.; Trøjelsgaard, K.; Forchhammer, M. C., 2013, Shorter Flowering Seasons and Declining Abundance of Flower Visitors in a Warmer Arctic, Nature Climate Change, 3, 759-763, https://doi. org/10.1038/Nclimate1909

Johnson, H. B., 1975, Plant Pubescence: An Ecological Perspective, Botanical Review, 41, 233-258.

Jones, H., 2013, Plants and Microclimate: A Quantitative Approach to Environmental Plant Physiology, $3^{\text {rd }}$ Ed., Cambridge University Press, Cambridge,UK, DOI:10.1017/CBO9780511845727

Kevan, P. G., 1970, High Arctic Insect-Flower Relations: the Inter-Relationships of Arthropods and Flowers at Lake Hazen, Ellesmere Island, N. W. T., Canada, $\mathrm{Ph}$. D. Dissertation, University of Alberta, Edmonton, Alberta, Canada.

Kevan P. G., 1972, Heliotropism in Some Arctic Flowers, Canadian Field-Naturalist, 86, 41-44.

Kevan P. G., 1975, Sun-Tracking Solar Furnaces in High Arctic Flowers: Significance for Pollination and Insects, Science, 189, 723-726.

Kevan, P. G., 1989, Thermoregulation in Arctic Insects and Flowers: Adaptation and Co-Adaptation in Behaviour, Anatomy, and Physiology, Thermal Physiology 1989, Proceedings of the International Symposium on Thermal Physiology, Tromsø, Norway, 16-21 July 1989, Excerpta Medica, Ed. J. B. Mercer, Elsevier Science Publishers B. V., Netherlands, 747-753.

Kevan, P. G., 1990, Sexual Differences in Temperatures of Blossoms on a Dioecious Plant, Salix arctica (Salicaceae): Significance for Life in the Arctic, Arctic and Alpine Research, 22, 283-289.

Kevan, P. G., 2007, Diaheliotaxis and Ombrophobia in an Anthophilous High Arctic Midge, Smittia velutina (Lundbeck, 1898) (Chironomidae), Chironomus newsletter on Chironomidae Research, 20, 29-31.

Kevan P. G., 2013, Mythical Clytie's Gyrations Still Spin at the Top of the World, Journal of Pollination Ecology - Pollination Magazine, http://jpollecol.blogspot.com/2013/10/mythical-clyties-gyrationsstill-spin.html

Kevan, P. G.; Sudarsan R.; Nunes-Silva, P., 2018, Short Communication: Thermal Regimes in Hollow Stems of Herbaceaous Plants - Concepts and Models, International Journal of Biometeorology, 62, 2057-2062.

Kevan, P. G.; Tikhmenev, E. A.; Usui, M., 1993, Insects and Plants in the Pollination Ecology of the Boreal Zone, Ecological Research, 8, 247-267.

Kjellberg B.; Karlsson S.; Kerstensson I., 1982, Effects of Heliotropic Movements of Flowers of Dryas octopetala L. on Gynoecium Temperature and Seed Development, Oecologia, 54, 10-13.

Kooi, C. van der; Elzenga J. T. M.; Dijsterhuis J.; Stavenga D. G., 2017, Functional Optics of Glossy Buttercup Flowers, Journal of the Royal Society Interface, 14, 127, 20160933.

Krannitz, P. G., 1996, Reproductive Ecology of Dryas integrifolia in the high Arctic Semi-Desert, Canadian Journal of Botany, 74, 1145-1460.

Krog, J., 1955, Notes on Temperature Measurements Indicative of Special Organisation in Arctic and Subarc- tic Plants for Utilization of Radiated Heat from the Sun, Physiologia Plantarum, 8, 836-839.

Lack, A. J., 1976, Flower-Basking by Insects in Britain, Watsonia, 11, 143-144.

McKee, J.; Richards, A. J., 1998, Effect of Flower Structure and Flower Colour on Intrafloral Warming and Pollen Germination and Pollen-Tube Growth in Winter Flowering Crocus L. (Iridaceae), Botanical Journal of the Linnean Society, 128, 369-384.

Meier, S. L., 1995, Ecology of Two Endophytophagous Insects of Pedicularis (Scrophulariaceae) in the High Arctic, M. Sc. Dissertation, Department of Biology, Laurentian University, Sudbury, Ontario, Canada.

Michaletz, S., 2018, Evaluating the Kinetic Basis of Plant Growth from Organs to Ecosystems, New Phytologist, 219, 37-44.

Miller-Struttmann, N. E.; Geib, J. C.; Franklin, J. D.; Kevan, P. G.; Holdo, R. M.; Ebert-May, D.; Lynn, A. M.; Kettenbach, J. A.; Hedrick, E.; Galen, C., 2015, Functional Mismatch in a Bumble Bee Pollination Mutualism under Climate Change, Science, 349, 1541-1544, DOI: 10.1126/science.aab0868

Mølgaard, P., 1982, Temperature Observations in High Arctic Plants in Relation to Microclimate in the Vegetation of Peary Land, North Greenland, Arctic and Alpine Research, 14, 105-115.

Mølgaard, P., 1989, Temperature Relations of Yellow and White flowered Papaver radicatum in North Greenland, Ibid., 21, 83-90.

Post, E., 2013, Ecology of Climate Change: The Importance of Biotic Interactions, Princeton Monographs in Population Biology, 52, Princeton University Press, Princeton, NJ, USA, Oxford, UK.

Savile, D. B. O., 1972, Artic Adaptations in Plants, Canada Department of Agriculture Monograph, 6, Information Canada, Ottawa Catalogue, A54-3/6.

Serrano, A. M.; Arana, M. V.; Vanhaelewyn, L.; Ballaré, C. L.; Straeten, D. Van Der; Vandenbussche, F., 2018, Following the Star: Inflorescence heliotropism, Environmental and Experimental Botany, 147, 75-85.

Shamurin, V. F., 1966, Seasonal Rhythm and Ecology of Flowering Plants of Tundra Communities of Northern Yakutia, Ed. B. A. Tikhomirov, Adaptations of the Plants of the Arctic to the Environment, Rast. Krain. Severa SSSR Osv., Moscow, Leningrad, Nauka, 8, 5-125.

Shrestha, M.; Garcia, J. E.; Bukovac, Z.; Dorin, A.; Dyer, A. G., 2018, Pollination in a New Climate: Assessing the Potential Influence of Flower Temperature Variation on Insect Pollinator Behavior, PLoS ONE, 13, 8, e0200549

Sørensen, T., 1941, Temperature Relations and Phenology of the Northeast Greenland Flowering Plants, Meddeleser om Grønland, 125, 1-305.

Stanton, M. L.; Galen, C., 1989, Consequences of Flower Heliotropism for Reproduction in an Alpine Buttercup (Ranunculus adoneus), Oecologia, 78, 477-485.

Stanton, M. L.; Galen, C., 1993, Blue-Light Controls Solar Tracking by Flowers of an Alpine Plant, Plant Cell and Environment, 16, 983-989.

Tikhmenev, E. A., 1976, Anthecology of Wrangel Island Plants, Bot. Zh., 61, 2, 164-176 [In Russian].

Tikhmenev, E. A., 1984, Pollination and Self-Pollination Potential of Entomophilous Plants of Arctic and 
Mountain Tundra of North-East of USSR, Soviet $J$. of Ecology, 4, 8-15.

Tikhmenev, E. A., 1997, The Reproductive Features of the Northern Angiosperms as a Factor of Plant Diversity and Community Stability, Opera Botanica, 132, 67-76.

Tikhomirov, B. A.; Shamurin, V. F.; Shtepa, V. S., 1960, The Temperature of Arctic Plants, Izv. Akad. Nauk SSSR, 3, 25, 429-442 [In Russian].

Warren Wilson, J., 1957, Observations on the Temperatures of Arctic Plants and their Environment, Journal of Ecology, 45, 499-531.
Went, F. $W ., 1953$, The Effect of Temperature on Plant Growth, Annual Review of Plant Physiology, 4, 347-362.

Wheeler, H. C.; Høye, T. T.; Schmidt, N. M.; Svenning, J.-C.; Forchhammer, M. C., 2015, Phenological Mismatch with Abiotic Conditions - Implications for Flowering in Arctic Plants, Ecology, 96,775-787.

Zhang, S.; Ai, H.-L.; Yu, W.-B.; Wang, H.; De-Zhu, L., 2010, Flower Heliotropism of Anemone Rivularis (Ranunculaceae) in the Himalayas: Effects on Floral Temperature and Reproductive Fitness, Plant Ecology, 209, 301-312.

\title{
ТЕМПЕРАТУРА ВНУТРИ ЦВЕТКОВ И СТЕБЛЕЙ: ВОЗМОЖНАЯ РОЛЬ В РЕПРОДУКЦИИ РАСТЕНИЙ НА СЕВЕРЕ
}

\author{
П. Г. Кеван ${ }^{1}$, Е. А. Тихменев ${ }^{2}$, П. Нуньес-Силва ${ }^{1}$ \\ ${ }^{1}$ Школа экологических наук, Университет Гвелфа, Гвелф, Онтарио, Канада \\ ${ }^{2}$ Федеральное государственное бюджетное учреждение науки \\ Институт биологических проблем Севера Дальневосточного отделения \\ Российской академии наук, Магадан, Россия
}

Температурные режимы внутри цветков и стеблей показывают, что нагревание посредством солнечного освещения (солярное) приводит к повышению температур по сравнению с окружающим воздухом. Дополнительное тепло играет важную роль в развитии репродуктивных органов (спорофиллов) и, предположительно, росте стеблей. Изучив публикации по температурным режимам внутри цветов, мы обнаружили, что по температуре внутри стеблей они практически отсутствуют. Температуры, превышающие температуру окружающего воздуха в цветах и внутри полых стеблей, изменяются, но могут доходить примерно до $10^{\circ} \mathrm{C}$. Проведенное нами беглое обследование обнаружило, что на территории Магадана полые стебли распространены шире (18:4 вида), чем в других частях света (около 50\%). Полученные нами результаты фиксирования температур в полых стеблях четырех видов травянистых растений (овса Avena sativa, одуванчика Taraxacum officinale, чертополоха Cirsium setosu и тысячелистника Ptarmica salicifolia) при прямой солнечной освещенности в Магадане показали превышение температур приблизительно от 1 до $7^{\circ} \mathrm{C}$ в зависимости от вида, местонахождения и других факторов. Цветение, завязывание семян, развитие цветков и семян - все это требует роста и развития растений, которое стимулируется теплом. Микрометеорология внутри органов растений существенно влияет на общее воздействие погоды и температуры посредством биофизических процессов, которые позволяют растению адаптироваться для поглощения тепла от солнечного излучения. Будучи предварительным, наше исследование открывает дверь в слабоизученную область микрометеорологии.

Ключевые слова: микротеплица, полые стебли, рост растения, микрометеорология, развитие растений, изменение климата, экология флоры, гелиотропизм. 